\title{
The Effects of Academic Self-Efficacy on Vocational Students Behavioral Engagement at School and at Firm Internships: A Model of Engagement-Value of Achievement Motivation
}

\author{
Jon-Chao Hong ${ }^{1}$, Hui-Ling Zhang ${ }^{2, *}$, Jian-Hong $\mathrm{Ye}^{3, * \mathbb{C}}$ and Jhen-Ni Ye ${ }^{4}$ \\ 1 Research Institute of Learning Science, National Taiwan Normal University, No. 162 Heping East Road \\ Section 1, Taipei 106, Taiwan; tcdahong@gmail.com \\ 2 Research Institute of Lifelong Education, Central China Normal University, No. 152 Luoyu Road, \\ Wuhan 430000, China \\ 3 Dhurakij Pundit University, 110/1-4 Prachachuen Rd., Laksi, Bangkok 10210, Thailand \\ 4 Graduate Institute of Technological \& Vocational Education, National Taipei University of Technology, \\ 1, Section 3, Zhongxiao E. Rd., Taipei 106, Taiwan; jhen13211321@gmail.com \\ * Correspondence: nr770485530@gmail.com (H.-L.Z.); kimpo30107@yahoo.com.tw (J.-H.Y.)
}

check for

updates

Citation: Hong, J.-C.; Zhang, H.-L.; Ye, J.-H.; Ye, J.-N. The Effects of Academic Self-Efficacy on Vocational Students Behavioral Engagement at School and at Firm Internships: A Model of Engagement-Value of Achievement Motivation. Educ. Sci. 2021, 11, 387. https://doi.org/ 10.3390/educsci11080387

Academic Editor: Neil Gordon

Received: 2 June 2021

Accepted: 20 July 2021

Published: 28 July 2021

Publisher's Note: MDPI stays neutral with regard to jurisdictional claims in published maps and institutional affiliations.

Copyright: (c) 2021 by the authors. Licensee MDPI, Basel, Switzerland. This article is an open access article distributed under the terms and conditions of the Creative Commons Attribution (CC BY) license (https:// creativecommons.org/licenses/by/ $4.0 /)$.

\begin{abstract}
There has been a marked increase in internship participation in recent decades. Many students who take cooperative programs consider internships to be the most appropriate entry point into their chosen careers. However, few studies have investigated factors related to internships from an engagement-value perspective that can influence the intention to continue doing internships with firms. This study concluded that academic self-efficacy was positively related to school and firm engagement; school engagement did not significantly relate to, but firm engagement did positively relate to the perceived usefulness of internships; and perceived usefulness of internships was positively related to intention to continue doing internships.
\end{abstract}

Keywords: academic self-efficacy; engagement; intention to continue doing internships; internships; perception of usefulness; vocational school

\section{Introduction}

By providing students with a space combining theoretical study with practice, firmbased internships may enable them to not only acquire relevant theoretical knowledge but also to gain relevant practical experience as a means of deepening their comprehension of previously studied theoretical material [1]. Prior research [1,2] has indicated that this type of comprehensive pedagogical methodology is beneficial to the development of students' academic and practical abilities during the learning process. For example, internships are an important means by which the educational experience of students is enriched by allowing them to participate in authentic work environments [3]. Considering this, school workshops provide learning environments for hands-on simulated learning, but not realistic experience [4]. Moreover, school workshops are a specific learning practice instructed by teachers, and learning is around knowledge reproduction without specific progression [5]. On the other hand, learning at firms involves realistic practice, where the role of production is a requirement [5]. In schools, teachers can reduce challenging conditions for students to practice or learn knowledge [6,7], whereas in firms, principles of awards and punishments halt behavioral concerns. Therefore, working life during internships has been said to make students feel less safe and less certain [8]. Nevertheless, vocational high school students are required to attend internships before they graduate from school despite the fact that the learning progression through firms is characterized by uncertainties that can undermine goal pursuit and subsequent attainment. Thus, this study aimed to explore how vocational school students position themselves as they engage in school workshop learning and firm internships. 
A nationwide study in Canada found that the focus of internship research has mainly been on learning outcomes [9], or on the benefits that internship participation can bring to students' future careers [10], rather than on contrasting the value of school engagement to firm engagement. According to the control-value theory of achievement motivation (CVTAM) [11], the greater the correspondence between value and invested effort, the greater an individual's investment of effort in work or study will be [12]. The concept of CVTAM is often used to explain the relationship between perception of usefulness and engagement within the setting of vocational education [3]. In fact, if after having conscientiously engaged in an internship students believe it to be beneficial, then they are more likely to be willing to continue with internships. Thus, this study proposed the engagement-value of achievement motivation model (EVAMM) to study the interrelatedness among those psychological traits and states related to school-based and firm-based learning.

Each individual may have different psychological traits which affect their attitude toward engaging in an activity [13]. Previous studies have revealed that individual students' academic self-efficacy levels align with their own performance and attitude [14] and reinforce learning effects [15]. However, such an analysis in the field of vocational education is considered fragmented in association with these two types of engagement programs as mediators that might shape the effects of self-efficacy on the outcome variable. Therefore, by using EVAMM, the present study investigated the combined effects of both school-based and firm-based learning on vocational students' perceived usefulness of internships and intention to continue doing internships.

\subsection{Academic Self-Efficacy}

Self-efficacy denotes the level of confidence people have in their own ability to apply pre-existing skills in order to complete given work-related tasks [16]. Self-efficacy theory explains how self-efficacy affects individual behavior and effectiveness [17]. From selfefficacy theory it is known that the level of confidence that individuals have in their ability to complete a task influences their behavior. In a majority of cases, people will choose to participate in activities in which they are full of confidence and will avoid activities in which they have low confidence and in which they may fail [18]. For example, in an academic context, self-efficacy is often expressed in terms of academic self-efficacy [19,20], and is associated with academic achievement $[19,21]$. However, many vocational high school students' self-efficacy and self-esteem are very low [22]. Therefore, on the basis of the control-value theory of achievement motivation, it is possible to understand that academic self-efficacy will predict individual behavior in cooperative internship programs related to vocational school students.

\subsection{Behavioral Engagement}

Although engagement is a relatively new concept in the academic literature, it has become a focal point for many researchers in education [23]. Researchers generally believe that engagement is comprised of three parts, namely behavioral, affective, and cognitive [24,25]. Moreover, workers who actively engage in work are more energetic [26], are faster at responding to new information [27], receive higher points in role behavior measurements [28], have greater concentration, and exert more effort [27]. However, students who are deficient in behavioral engagement are unable to realize high-quality learning) [29]. In this study, we took behavioral engagement to mean engagement at schools and firms. In accordance with the engagement-value of achievement motivation, in this research school engagement refers to students' level of behavioral engagement at school, whereas intern engagement refers to students' level of behavioral engagement while conducting internships in firms. Thus, this research aimed to understand how vocational students engage at schools and in firms to learn practical skills. 


\subsection{Perceived Usefulness of and Intention to Continue Doing Internships}

Technology acceptance model (TAM) was proposed by Davis in 1986 with the purpose of explaining the behavior of the adoption of technology [30]. According to TAM, the intention of an individual to accept a new technology depends on the individual's cognitive response to the technology. Moreover, TAM is the most widely used framework for investigating users' attitudes and intentions to adopt behavior. Previous research from beneficiary-related (person involved) perspectives has extended the TAM model to research on educational policy and planning acceptance levels [31,32]; attitude elements were included within TAM, but recent research has removed them from the model because their impact within the framework is very weak $[33,34]$. However, the perception of usefulness was initially defined as "an individual's belief that adopting a given behavior will increase his or her level of performance in completing a task" [35]; additionally, intention to continue is an important element in the understanding of an individual's subsequent behavior [36].

Related research takes individuals' behavior after application as a basis for understanding intention to continue with that behavior [37]. As internships possess enormous potential value, internships in vocational education have received much attention, and their level of implementation has been steadily increasing [1]. This research is based on the perception that internships are useful and the intention to continue internship behavior is a means of examining the advantages of cooperative education.

\section{Method}

\subsection{Research Model}

By extending the control-value theory of achievement motivation to the engagementvalue of motivation, this research proposed the EVAMM and aimed to understand the interrelatedness between academic self-efficacy, two types of behavioral engagement, perceived usefulness of internships, and vocational high school students' intention to continue with internships. In comprehensively arranging the literature and its empirical support, we constructed a research model as shown in Figure 1.

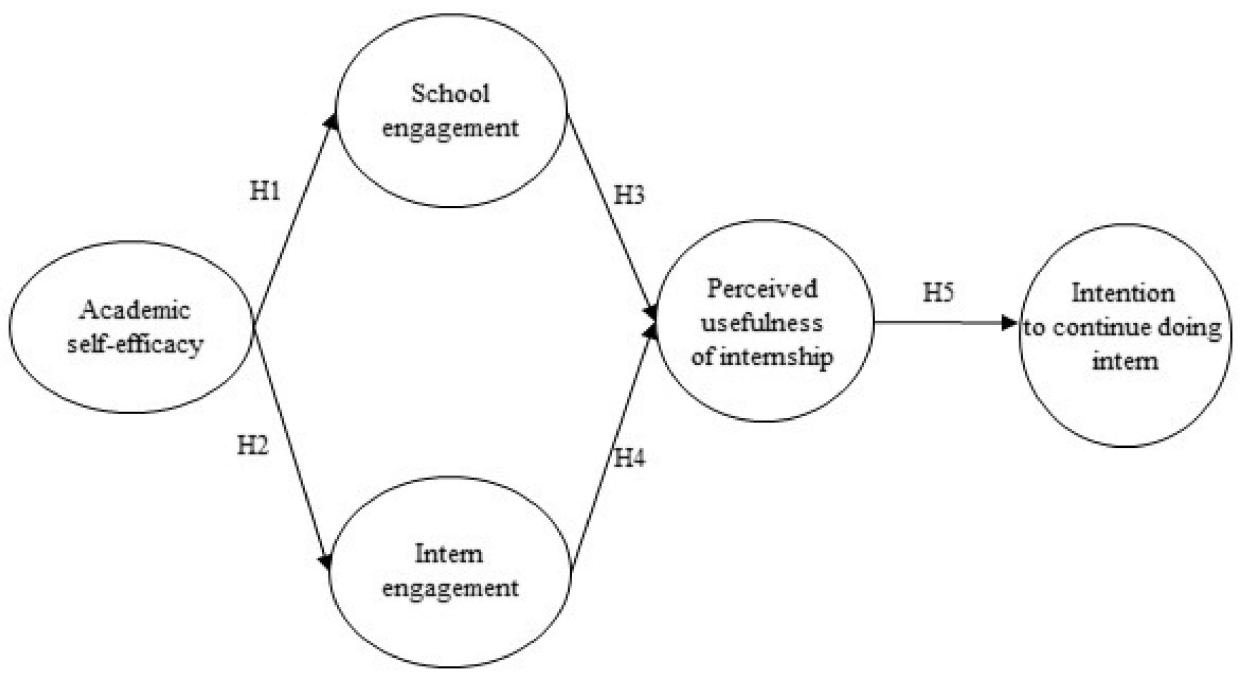

Figure 1. Research model.

\subsection{Research Hypotheses}

\subsubsection{Academic Self-Efficacy Relevant to Behavioral Engagement}

Self-efficacy and work engagement show a pronounced positive correlation [27]. Selfefficacy can influence individuals' ways of thinking and their emotional reactions; the stronger an individual's self-efficacy is, the greater the learning engagement [38]. That is to say, an individual with a higher level of academic self-efficacy possesses greater internal motivation to see hope in the future and is better equipped to withstand negative 
experiences and pessimistic moods, thereby finding it easier to engage positively in the learning process and to formulate long-term study plans $[39,40]$. In relation to the programs of cooperative education, this research investigated the relationship between students learning self-efficacy, their behavioral engagement at school, and their engagement in firm internships. It posits the following hypotheses:

Hypothesis 1 (H1). Academic self-efficacy is positively related to behavioral engagement in schools.

Hypothesis 2 (H2). Academic self-efficacy is positively related to behavioral engagement in firm internships.

\subsubsection{Behavioral Engagement Relevant to Perception of Usefulness}

School engagement is an important predictive factor of success, as students invest a great deal of time and energy in the learning process and are thus immersed in learning activities [41]. Work engagement is beneficial at an individual and collective level as it influences the level of completion of individual and work tasks [42]. In fact, previous research has already established that school engagement and perception of usefulness are related [43]. Engagement is the link between the regulation of individual attitude, behavior, and performance; concerted engagement promotes improvement in educational outcomes [44,45]. For example, in studies of students from Portugal, Spain, and the Netherlands [46], it was discovered that school engagement and perception of usefulness displayed a positive correlation. However, whether the vocational students' engagement at schools and in firms as the perception of the intern's usefulness, and so posits the following research hypotheses:

Hypothesis 3 (H3). School engagement is positively related to perceived usefulness of internship.

Hypothesis 4 (H4). Intern engagement is positively related to perceived usefulness of internship.

\subsubsection{Perceived Usefulness and Intention to Continue with Firm Internships}

Internships are an important part of preparing fourth-year college students for the job market. By means of satisfying students' internship requirements and increasing internship effectiveness, firms can encourage students to apply their already acquired cognitive capabilities to carrying out internship-related tasks appropriately [47]. However, after participating in an internship, what is the motivation for the participant to continue? Perceived usefulness has an especially high predictive ability in relation to "continued adoption," and perception of usefulness is considered an important causative factor in intention to continue with a behavior [37]. For example, if students discover that their previous learning behavior has not led to the expected effectiveness and perceive "learning engagement" as being of no use and failing to produce the expected results, this may result in them becoming distracted, unproductive, and finally unwilling to continue learning [48]. The effectiveness of internships promotes the intention to continue with internships [49]. For example, a study of internships for Thai university students showed that learning and experiential outcomes shaped the way students made future career choices [50]. In addition, Taiwanese scholars have suggested that the impact of training is an influential factor that affects student career performance [51]. In understanding the connection between perceived usefulness of internship and continuous intention to take in vocational students in the context of cooperative education, this research posits the following hypothesis:

Hypothesis 5 (H5). Perceived usefulness is positively related to intention to continue doing internships.

\subsection{Procedure}

This research used purposive sampling to recruit those students enrolled in hospitality studies in Northern Taiwan who were participating in a cooperative education program with at least one year's experience of internship in a firm. This study revised the past research instrument and invited three educational experts to conduct a face validity review. 
Subsequently, 10 students completed the questionnaire to confirm its content validity. Then, the questionnaire was posted on LINE, an Internet messaging system, and we contacted teachers asking them to inform their students to download and complete the questionnaire. Five teachers from five vocational schools assisted with its distribution, and after those students agreed to complete the survey, 100 samples were targeted in each school. Data were then collected for confirmatory factor analysis (CFA) and structural equation modelling (SEM) in order to test the research model.

\subsection{Participants}

In November 2018, a total of 332 completed questionnaires were collected via LINE. Among them, 132 (41\%) were completed by males and $190(59 \%)$ by females, where $45(14 \%)$ were 15 years old, 135 ( $42 \%$ ) were 16 years old, $117(36 \%)$ were 17 years old, and $24(8 \%)$ were 18 years old.

\subsection{Questionnaire}

The development and modification of the questionnaire: on the basis of the research literature and referring to previous questionnaires for use in the investigation, a 5-point Likert scale was used ranging from 1 (Strongly disagree) to 5 (Strongly agree). Since this study adopted a confirmatory approach, the item validity and construct reliability and validity were tested.

Academic self-efficacy: This research questionnaire was a modified version of Bandura's self-efficacy scale [52], where self-efficacy refers to one's confidence in one's ability to successfully complete tasks; it also represents a promise in regards to setting objectives. In this research, academic self-efficacy is taken as self-efficacy in relation to the ability and confidence to complete tasks.

School engagement: Behavioral school engagement refers to attendance, participation, and positive conduct in school [53]. This research questionnaire adapted their definition as a means of understanding the engagement of vocational students while learning at school.

Intern engagement: This research questionnaire modified the nine-item Utrecht Work Engagement Scale [54] to understand vocational high school students' engagement when taking part in firm internships.

Perceived usefulness of internship: This research questionnaire drew on Vekiri's [55] work related to the question of usefulness as a means of measuring students' effectiveness in their internships; an example item is, "Through an internship, I acquired necessary relevant knowledge."

Intention to continue doing intern: This research questionnaire modified the previously corroborated research questionnaire by Chiu et al. [56], as a way of attaining verification goals. In this research, intention to continue doing intern at firms refers to vocational students' intention to continue to go to firms for internships.

\section{Results}

\subsection{Measuring Instrument}

\subsubsection{Item Analysis}

To begin with, the first-order confirmatory factor analysis (CFA) was adopted to test the internal validity of each item. Table 1 . shows that the $\chi^{2}$ value is less than 5 , that the degree of freedom is less than 5, that the GFI is greater than 0.80 and that the RMSEA is greater than 0.80 . On the basis of the simplified model, a residual value over 0.70 is necessary to reduce the items of the questionnaire $[57,58]$. Therefore, items related to academic self-efficacy were reduced from eight to five; school engagement was reduced from seven to five items; intern engagement was reduced from six to five; perceived usefulness of internship from six to five; and intention to continue doing intern from seven to five. 
Table 1. First-order of confirmatory analysis.

\begin{tabular}{ccccccc}
\hline Constructs & $\chi^{2}$ & $d f$ & $\chi^{2} / \mathbf{d f}$ & RMSEA & GFI & AGFI \\
\hline Threshold value & - & - & $<5$ & $<0.10$ & $>0.80$ & $>0.80$ \\
Academic self-efficacy & 14.8 & 5 & 2.952 & 0.092 & 0.977 & 0.932 \\
School engagement & 9.3 & 5 & 1.855 & 0.061 & 0.984 & 0.953 \\
Intern engagement & 5.9 & 5 & 1.189 & 0.029 & 0.990 & 0.970 \\
Usefulness of internship & 13.8 & 5 & 2.751 & 0.087 & 0.979 & 0.936 \\
Intention to continue & 9.1 & 5 & 1.816 & 0.059 & 0.985 & 0.956 \\
doing internships & & & & & & \\
\hline
\end{tabular}

Once items were removed after confirming internal validity, items from each of the constructs were subjected to external validity confirmation. The numerical value of each item among those completing the questions ranged from $27 \%$ before to $27 \%$ after; if the $t$ value (critical ratio) is greater than $3\left({ }^{* * *} p<0.001\right)$, then external validity is considered significant [59]. Table 2 shows a $t$ value higher than $8.37\left(^{* * *} p<0.001\right)$, which is to say that all of the items could be applied to this research [60].

Table 2. Reliability and validity analysis.

\begin{tabular}{|c|c|c|c|c|}
\hline Constructs and Items & $M$ & $S D$ & FL & $t$-Value \\
\hline \multicolumn{5}{|l|}{ Academic self-efficacy: } \\
\hline \multicolumn{5}{|l|}{$\mathrm{M}=3.73, \mathrm{SD}=0.74, \mathrm{CR}=0.84, \mathrm{AVE}=0.67, \alpha=0.84$} \\
\hline 1. I believe that as long as I study diligently, I will be able to master skills. & 3.96 & 0.78 & 0.71 & 13.61 \\
\hline 2. I have confidence in my mastery of skills. & 3.53 & 0.71 & 0.71 & 15.87 \\
\hline 3. As long as I am diligent, I can master all of the skills learnt during the internship. & 3.85 & 0.74 & 0.85 & 17.44 \\
\hline 4. During classes at school, I can actually understand the content. & 3.50 & 0.71 & 0.63 & 11.22 \\
\hline $\begin{array}{l}\text { 5. During the internship, I believe that as long as I work hard, I can become proficient in skills. } \\
\text { School engagement: }\end{array}$ & 3.84 & 0.76 & 0.79 & 16.58 \\
\hline \multicolumn{5}{|l|}{$\mathrm{M}=3.44, \mathrm{SD}=0.77, \mathrm{CR}=0.81, \mathrm{AVE}=0.66, \alpha=0.81$} \\
\hline 1. While attending class at school, I submit reports or homework on time. & 3.64 & 0.90 & 0.61 & 17.80 \\
\hline 2. While attending class at school, I actively engage in discussions with other students. & 3.33 & 0.72 & 0.65 & 14.85 \\
\hline $\begin{array}{l}\text { 3. While attending class at school, I search out various sources of information in preparing } \\
\text { reports or homework. }\end{array}$ & 3.34 & 0.78 & 0.76 & 14.32 \\
\hline 4. While attending class at school, if I have a question I consult the teacher. & 3.40 & 0.66 & 0.64 & 11.64 \\
\hline $\begin{array}{l}\text { 5. While attending class at school, if I encounter a problem I attempt to resolve it myself first, } \\
\text { only consulting the teacher if I am unable to do so. }\end{array}$ & 3.52 & 0.77 & 0.74 & 16.09 \\
\hline \multicolumn{5}{|l|}{ Intern engagement: } \\
\hline \multicolumn{5}{|l|}{$\mathrm{M}=3.88, \mathrm{SD}=0.79, \mathrm{CR}=0.85, \mathrm{AVE}=0.64, \alpha=0.84$} \\
\hline 1. When doing an internship, I try my best to learn new skills every day. & 3.94 & 0.78 & 0.80 & 14.83 \\
\hline $\begin{array}{l}\text { 2. When doing an internship, I cooperate with the person in charge and do the tasks he or she } \\
\text { assigns me. }\end{array}$ & 4.15 & 0.74 & 0.79 & 17.12 \\
\hline $\begin{array}{l}\text { 3. When doing an internship, if other people need help, I immediately offer my } \\
\text { full assistance. }\end{array}$ & 3.88 & 0.79 & 0.77 & 15.65 \\
\hline 4. When doing an internship, I pay attention to professional ethics while completing tasks. & 4.05 & 0.75 & 0.81 & 18.71 \\
\hline $\begin{array}{l}\text { 5. When doing an internship, if I encounter a problem I work tirelessly to resolve it and feel } \\
\text { uneasy if I am unable to do so. }\end{array}$ & 3.39 & 0.89 & 0.64 & 8.37 \\
\hline \multicolumn{5}{|l|}{ Usefulness of internship: } \\
\hline \multicolumn{5}{|l|}{$\mathrm{M}=3.74, \mathrm{SD}=0.79, \mathrm{CR}=0.91, \mathrm{AVE}=0.68, \alpha=0.91$} \\
\hline 1. The internship deepens my understanding of theoretical knowledge. & 3.69 & 0.77 & 0.82 & 17.77 \\
\hline 2. The internship promotes my mastery of skills. & 3.76 & 0.79 & 0.86 & 21.49 \\
\hline 3. I learn more relevant knowledge in the internship than in classroom study. & 3.84 & 0.84 & 0.87 & 18.50 \\
\hline 4. I can study the kind of relevant knowledge that I need by participating in the internship. & 3.78 & 0.77 & 0.82 & 19.24 \\
\hline 5. I feel that the internship can improve my engagement with classroom study. & 3.64 & 0.80 & 0.73 & 16.21 \\
\hline \multicolumn{5}{|l|}{ Intention to continue doing intern: } \\
\hline \multicolumn{5}{|l|}{$\mathrm{M}=3.70, \mathrm{SD}=0.82, \mathrm{CR}=0.93, \mathrm{AVE}=0.74, \alpha=0.93$} \\
\hline 1. In the future I will still enthusiastically participate in internships. & 3.75 & 0.85 & 0.85 & 19.96 \\
\hline $\begin{array}{l}\text { 2. Regardless of whether or not I am satisfied with performance in this internship, I will } \\
\text { continue to participate in internships. }\end{array}$ & 3.79 & 0.82 & 0.89 & 21.27 \\
\hline $\begin{array}{l}\text { 3. Even if the internship does not necessarily assist in going to a school of higher grade (or } \\
\text { finding work), I will still continue to participate in internships. }\end{array}$ & 3.66 & 0.78 & 0.85 & 18.70 \\
\hline $\begin{array}{l}\text { 4. Regardless of whether or not I am satisfied with the results of this internship, I will still } \\
\text { continue to participate in internships. }\end{array}$ & 3.73 & 0.80 & 0.91 & 22.17 \\
\hline $\begin{array}{l}\text { 5. I will especially look out for announcements about internship activities and will want to } \\
\text { participate in them. }\end{array}$ & 3.58 & 0.84 & 0.80 & 18.27 \\
\hline
\end{tabular}




\subsubsection{Construct Reliability and Validity Analysis}

Reliability: Composite reliability (CR) confirmation was firstly tested. If $\mathrm{CR}$ is higher than 0.70 , this means that composite reliability is confirmed [57]. Table 2 shows that the CR value in this research was in all cases significantly greater than 0.70 ; thus, the questionnaire in this research met the requirement for the composite reliability threshold. Once again Cronbach's $\alpha$ was used to investigate the consistency of the questionnaire's internal constructs. Table 2 reveals that the $\alpha$ values of study self-efficacy, school engagement, intern engagement, intern usefulness, and intern intention were $0.84,0.81,0.84,0.91$ and 0.93 respectively; all were therefore in excess of the recommended value of $0.60[57,61]$.

Validity: Confirmation of convergence validity was firstly tested. Via confirmation, the AVE value for all constructs was above 0.61 , which was greater than the recommended value of 0.60 [62]. Additionally, the factor loadings (FL) of all of the items were between 0.61 and 0.91 , thus being in all cases higher than the recommended value of 0.60 . Therefore, the AVE and FLs satisfied convergence validity [63]. Furthermore, the average level of the extracted square root of variation levels of constructs was greater than the correlation coefficient between each of the constructs, indicating that each of the constructs comfortably exceeded a good level of differentiation [62]. Table 3 shows that in this research the average square root for the variability was 0.66 which was greater than the correlation coefficient of the individual constructs. This research therefore has good differentiation validity.

Table 3. Constructs discrimination validity.

\begin{tabular}{cccccc}
\hline Constructs & $\mathbf{1}$ & $\mathbf{2}$ & $\mathbf{3}$ & $\mathbf{4}$ & $\mathbf{5}$ \\
\hline 1. Academic self-efficacy & $(0.71)$ & & & & \\
2. School engagement & 0.45 & $(0.68)$ & & & \\
3. Intern engagement & 0.56 & 0.44 & $(0.73)$ & & \\
4. Perceived usefulness of internship & 0.56 & 0.32 & 0.64 & $(0.82)$ & \\
5. Intention to continue doing intern & 0.53 & 0.28 & 0.62 & 0.72 & $(0.86)$ \\
\hline
\end{tabular}

\subsection{Model Fit Analysis}

This study used AMOS20 to confirm the fit of the model. (1) In accordance with the absolute fit indicators put forward by using the Chi-square verification level and relative degree of freedom in order to confirm the model's degree of fit, the $\chi^{2} / \mathrm{df}=1.90$ was less than the threshold of 3, indicating that this model has an ideal level of fit [57]. (2) GFI and AGFI values are recommended to be higher than 0.80 [63]; a RMSEA value of 0.05 indicates that the model's level of fit is ideal; close to 0.08 indicates that the model's fit is good [63]. The GFI, AGFI, and RMSEA values of this research are $0.85,0.82$, and 0.06 respectively, and are all thus clearly in excess of the recommended standards. (3) Incremental fit models include the Normed Fit Index (NFI), Non Normed Fit Index (NNFI), Incremental Fit Index (IFI), Comparative Fit Index (CFI) and the Relative Fit Index (RFI). The incremental fit values of this research model are as follows: $\mathrm{NFI}=0.87, \mathrm{TLI}=0.96, \mathrm{CFI}=0.93$, $\mathrm{IFI}=0.93, \mathrm{RFI}=0.86$; the values are ranged $0.85-0.9$ in this study and fit threshold [63]. (4) Parsimonious Fit Measures include the Parsimonious Normed Fit Index (PNFI) and the Parsimonious Goodness of Fit Index (PGFI). The PNGI and PGFI values for this research are 0.78 and 0.71 , both higher than the recommended value of 0.50 [57]. Thus, the level of fit of this research model is excellent.

\subsection{Path Analysis}

Firstly, in regards to direct effect, the results show that academic self-efficacy is positively related to school engagement $\left(\beta=0.54^{* * *}, p<0.001\right)$ and intern engagement $\left(\beta=0.67^{* * *}, p<0.001\right)$. Intern engagement is positively related to intern usefulness ( $\left.\beta=0.73^{* * *}, p<0.001\right)$, but not school engagement $(\beta=0.17, p>0.05)$. Moreover, perceived usefulness is positively related to intention to continue doing internships $\left(\beta=0.79^{* * *}\right.$, $p<0.001$ ). Additionally, the explanatory power of the research path of this research was confirmed. In this study, academic self-efficacy explanatory power for school engagement 
was 0.29 , academic self-efficacy explanatory power for intern engagement was 0.47 , school engagement and intern engagement explanatory power for intern usefulness was 0.56 , and intern usefulness explanatory power for intention to continue doing internships was 0.62 , all clearly greater than the recommended value of 0.10 . Thus, on the basis of the aforementioned results, the variables in this research display good predictive power, as shown in Figure 2.

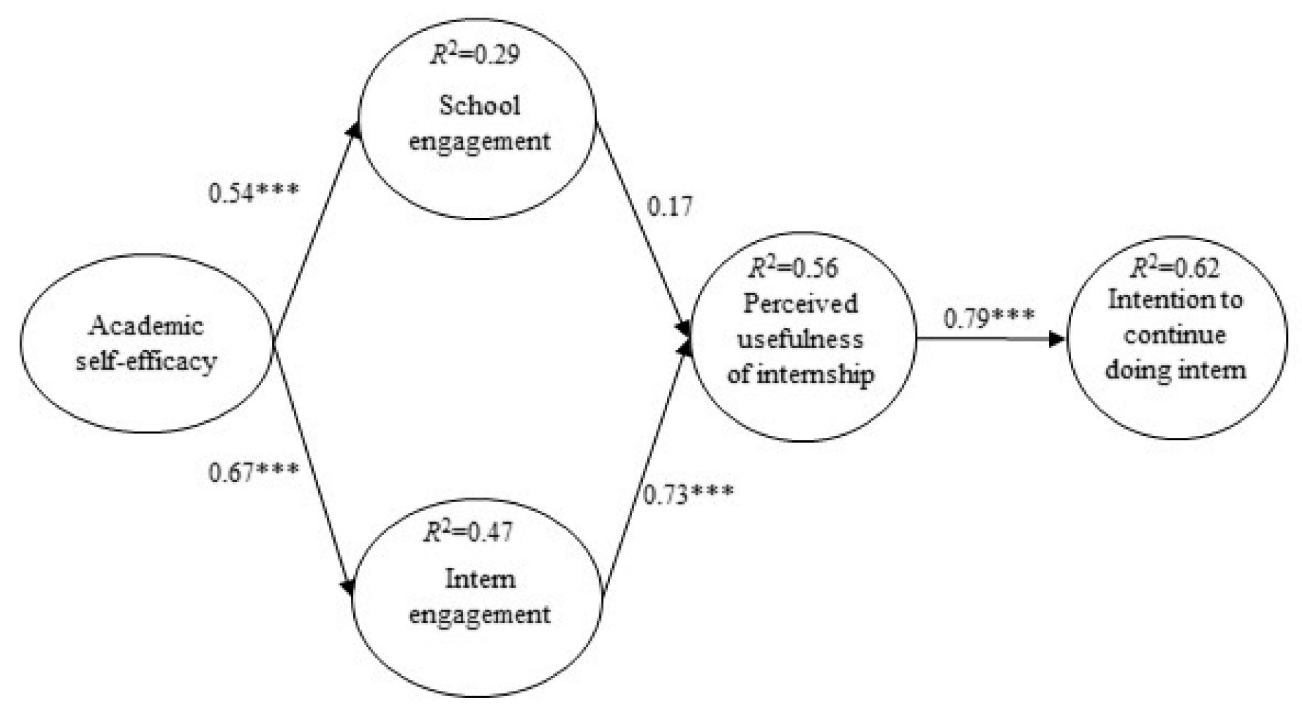

Figure 2. Verification of the research model. ${ }^{* * *} p<0.001$.

\subsection{Indirect Effect Analysis}

With regard to indirect effect, academic self-efficacy and intern usefulness was 0.51 and the confidence interval was [0.37, 0.67]; academic self-efficacy and level of intern engagement was 0.40 and the confidence interval was [0.30, 0.52]; intern engagement and level of internship usefulness was $0.58(p<0.05)$ and the confidence level was $[0.44,0.70]$. The confidence level did not generally include 0 , thus showing that academic self-efficacy and school engagement both have an indirect effect on level of intern usefulness. Additionally, academic self-efficacy also has an indirect effect on intern usefulness Table 4.

Table 4. Indirect effect analysis.

\begin{tabular}{cccccccc}
\hline \multirow{2}{*}{ Constructs } & \multicolumn{2}{c}{ Academic Self-Efficacy } & \multicolumn{2}{c}{ School Engagement } & \multicolumn{2}{c}{ Intern Engagement } \\
\cline { 2 - 7 } & $\boldsymbol{\beta}$ & $\mathbf{9 5 \%} \mathbf{C I}$ & $\boldsymbol{\beta}$ & $\mathbf{9 5 \%} \mathbf{C I}$ & $\boldsymbol{\beta}$ & $\mathbf{9 5 \%} \mathbf{C I}$ \\
\hline Perceived intern usefulness & $0.51^{* *}$ & {$[0.38,0.64]$} & & & \\
Intention to continue doing intern & $0.40^{* *}$ & {$[0.30,0.52]$} & 0.037 & {$[-0.08,0.17]$} & $0.58^{*}$ & {$[0.44,0.70]$} \\
\hline
\end{tabular}

\section{Discussion}

Based on the engagement-value of achievement motivation model, this study explored how vocational school students perceived themselves as they engaged in school workshop learning and firm internships that might shape the effects of academic self-efficacy as a mediator and outcome variable. The levels participants perceived were as follows: academic self-efficacy was $M=3.73, S D=0.57$; school engagement was $M=3.44, S D=0.77$; intern engagement was $M=3.88, S D=0.79$; perceived usefulness of internship was $M=3.74, S D=0.79$; and intention to continue doing internships was $M=3.70, S D=0.82$. These results show that the average of each construct was above 3.00, and the lowest among the constructs of this study was school engagement. The results seem to support previous arguments. For instance, learning at school is related to knowledge reproduction 
and specific progression, whereas learning at firms involves realistic practice, where the role of production is a requirement [5].

Self-efficacy is an important predictive factor of learning engagement [64,65]. In fact, an individual with a high level of self-efficacy will display greater persistence and will be more engaged in learning [66] and will also be more willing to undertake challenging tasks [67]. This research shows that students with high academic self-efficacy are more engaged in learning; on the other hand, students with low academic self-efficacy have lower levels of engagement at school. Thus, $\mathrm{H} 1$ matches that of previous research in finding that the academic self-efficacy of students is positively related to their school engagement.

Individuals possessing high self-efficacy tend to hope that tasks can be carried out smoothly and they can accept normal setbacks and failures rather than believing that they themselves lack value [40]. These individuals are more willing to accept the influence of unexpected occurrences in life and are more willing to energetically adopt measures for resolving problems. For students, internships are a means of experiencing work and developing themselves. Similarly, Huang et al. also pointed out that employees with high self-efficacy are unlikely to feel fatigued at work [68]. The results of this research show that students with high academic self-efficacy have higher levels of work engagement. Thus, $\mathrm{H} 2$ is supported.

Olivier et al. showed that behavioral engagement is an important indicator of perception of usefulness [17]. However, the results of this research showed that vocational students' school engagement and perceived usefulness of internship have no significant correlation. This might be caused by the type of classroom work at school which involves knowledge or principles that are planned but which do not really match the work environment. For example, some researchers believe that schools should focus on developing the overall abilities of students and that the mastery of skills is the goal of internships [1]. That is, H3 is not supported, indicating that the content of students' studies at school is not in practice related to internships, and learning engagement at school does not lead to a sense of the usefulness of internships.

Rose et al. stated that an internship is the experience of actually applying skills within the work environment and the accumulation of practical experience, promoting the mastery of skills [69]. Relevant research shows that the higher students' behavioral engagement during the intern process is, the higher their perception of usefulness will be [41]. In other words, after seriously engaging in the internship process, students feel that they have mastered the practical skills needed for future employment and that the internship is useful for them. Thus, H4 is supported.

Rakoczy et al. argued that perception of usefulness has a positive effect on learners' intention to continue with further learning [37]. Likewise, research results by Nooromid et al. argued that perception of usefulness has a positive influence on intention to continue [70]. For example, when individuals discover that adopting a given behavior increases effectiveness, they are more willing to employ that behavior. Another item of research conducted a related investigation, showing that perception of usefulness influences intention to continue [71]. Thus, $\mathrm{H} 5$ is positively supported and indicates that when the perceived usefulness in firm internships is high, the intention to continue is also high.

\section{Conclusions}

School and intern engagements can distinctly provide students with different learning and work experience. Taking EVAMM as the theoretical framework, this research explored the factors influencing the intention of vocational students to continue doing internships. When students have relatively high academic self-efficacy and after engaging in learning behavior, on the basis of experience they draw conclusions about its usefulness and decide whether they are willing to continue with internships. 


\subsection{Implications}

Vocational curricula need to comprise a combination of school-based and workplace learning. That is, after students have studied theoretical knowledge related to skills at school, they can then deepen their understanding of the theory and their level of application during their intern experience [72]. However, this study first explored and described such learning programs in a correlative way and gained deeper understanding of how two types of engagement relate to perceived usefulness of internships.

Students' engagement behaviors have been linked to a range of positive outcomes such as superior psychological adjustment [48]. Internships give students practical experience, connecting classroom study of theory with firm internships in which students' future success is energetically prepared while doubtlessly giving them an advantage in the future workplace. The results of this research make us focus on the main task of educators, scrutinizing how to meet in practice students' actual needs while keeping students involved in cooperative education programs.

\subsection{Limitations and Future Study}

Cinamon studied the impact of three antecedents (i.e., social support, number of working hours, and whether one has the freedom to choose to work) on three outcomes (i.e., life satisfaction, school grades, and academic behavior) among working adolescents [73] and found that low social support and the absence of freedom to choose to work were associated with lower academic behavior. However, those antecedents were not included in this study. Future studies may focus on how those antecedents impact on behavioral engagement between school-based and firm-based learning to understand the differential effect of some other aspects on the school-work relationship.

Although this research was carried out in the context of a cooperative education hospitality school, this research model can be applied to other contexts. In future research, the fundamental factors resulting in differences between behavioral engagement at school and in internships could be thoroughly investigated and researched. For example, on the basis of self-determination theory [74], one of the most widely accepted theories of individual motivation and behaviors, studies can examine whether the internal motivations leading to higher levels of engagement can also lead to higher levels of perceived usefulness of internship.

Author Contributions: Conceptualization, J.-C.H., H.-L.Z. and J.-H.Y.; data curation, H.-L.Z.; formal analysis, J.-H.Y. and J.-N.Y.; methodology, J.-C.H.; software, J.-N.Y.; supervision, J.-C.H.; writingoriginal draft, H.-L.Z. and J.-H.Y.; writing-review \& editing, J.-C.H. All authors have read and agreed to the published version of the manuscript.

Funding: This research received no external funding.

Institutional Review Board Statement: Not applicable.

Informed Consent Statement: Informed consent was obtained from all subjects involved in the study.

Data Availability Statement: The data presented in this study are available on request from the corresponding author.

Acknowledgments: This work was financially supported by the "Institute for Research Excellence in Learning Sciences" of National Taiwan Normal University (NTNU) from The Featured Areas Research Center Program within the framework of the Higher Education Sprout Project by the Ministry of Education (MOE) in Taiwan.

Conflicts of Interest: The authors declare no conflict of interest.

\section{References}

1. Stansbie, P.; Nash, R.; Chang, S. Linking internships and classroom learning: A case study examination of hospitality and tourism management students. J. Hosp. Leis. Sport Tour. Educ. 2016, 19, 19-29. [CrossRef]

2. Kolb, D.A. Experiential Learning: Experience as the Source of Learning and Development; Prentice-Hall: Englewood Cliffs, NJ, USA, 1984. 
3. Steinmayr, R.; Kessels, U. Good at school = successful on the job? Explaining gender differences in scholastic and vocational success. Personal. Individ. Differ. 2017, 105, 107-115. [CrossRef]

4. Khaled, A.; Gulikers, J.; Biemans, H.; Mulder, M. How authenticity and self-directedness and student perceptions thereof predict competence development in hands-on simulations. Br. Educ. Res. J. 2015, 41, 265-286. [CrossRef]

5. Gilje, Ø.; Erstad, O. Authenticity, agency and enterprise education studying learning in and out of school. Int. J. Educ. Res. 2017, 84, 58-67. [CrossRef]

6. $\quad$ Muijis, D.; Reynolds, D. Effective Teaching: Evidence and Practice; SAGE: Los Angeles, CA, USA, 2018.

7. Scott, T.M.; Hirn, R.; Cooper, J. Teacher and Student Behaviors: Keys to Success in Classroom Instruction; Rowman \& Littlefield Publishers: Lanham, MD, USA, 2017.

8. Whitty, G.; Wisby, E. Whose voice? An exploration of the current policy interest in pupil involvement in school decision-making. Int. Stud. Sociol. Educ. 2007, 17, 303-319. [CrossRef]

9. Hynie, M.; Jensen, K.; Johnny, M.; Wedlock, J.; Phipps, D. Student internships bridge research to real world problems. Educ. Train. 2011, 53, 45-56. [CrossRef]

10. Cheung, R.; Arnold, J. Antecedents of career exploration among Hong Kong Chinese university students: Testing contextual and developmental variables. J. Vocat. Behav. 2010, 76, 25-36. [CrossRef]

11. Pekrun, R.; Perry, R.P. Control-value theory of achievement emotions. In International Handbook of Emotions in Education; Pekrun, R., Linnenbrink-Garcia, L., Eds.; Routledge: New York, NY, USA, 2014; pp. 120-141.

12. Li, M.; Wang, Z.; You, X.; Gao, J. Value congruence and teachers' work engagement: The mediating role of autonomous and controlled motivation. Personal. Individ. Differ. 2015, 80, 113-118. [CrossRef]

13. Baek, Y.; Touati, A. Exploring how individual traits influence enjoyment in a mobile learning game. Comput. Hum. Behav. 2017, 69, 347-357. [CrossRef]

14. Talsma, K.; Schüz, B.; Norris, K. Miscalibration of self-efficacy and academic performance: Self-efficacy $\neq$ self-fulfilling prophecy. Learn. Individ. Differ. 2019, 69, 182-195. [CrossRef]

15. Wohn, D.Y.; Sarkar, C. Self-efficacy versus expertise. In Encyclopedia of Social Network Analysis and Mining; Alhajj, R., Rokne, J., Eds.; Springer: New York, NY, USA, 2018; pp. 2337-2338.

16. Bandura, A. Self-efficacy: Toward a unifying theory of behavioural change. Psychol. Rev. 1977, 84, 191. [CrossRef]

17. Olivier, E.; Archambault, I.; de Clercq, M.; Galand, B. Student self-efficacy, classroom engagement, and academic achievement: Comparing three theoretical frameworks. J. Youth Adolesc. 2019, 48, 326-340. [CrossRef]

18. Klassen, R.M.; Klassen, J.R. Self-efficacy beliefs of medical students: A critical review. Perspect. Med. Educ. 2018, 7, 76-82. [CrossRef]

19. Honicke, T.; Broadbent, J. The influence of academic self-efficacy on academic performance: A systematic review. Educ. Res. Rev. 2016, 17, 63-84. [CrossRef]

20. Schunk, D.H.; Pajares, F. The development of academic self-efficacy. In Development of Achievement Motivation; Wigfield, A., Eccles, J.S., Eds.; Academic Press: San Diego, CA, USA, 2002; pp. 15-31.

21. Brouwer, J.; Jansen, E.; Flache, A.; Hofman, A. The impact of social capital on study success among first-year university students. Learn. Individ. Differ. 2016, 52, 109-118. [CrossRef]

22. Kelly, S.; Price, H. Vocational education: A clean slate for disengaged students? Soc. Sci. Res. 2009, 38, 810-825. [CrossRef]

23. Berry, A.; Hammer, E. The relationship of accreditation and student engagement in a college of business: An internal, multi-year comparison of high impact practices. Int. J. Manag. Educ. 2018, 16, 43-51. [CrossRef]

24. Rocca, K.A. Student participation in the college classroom: An extended multidisciplinary literature review. Commun. Educ. 2010, 59, 185-213. [CrossRef]

25. Skinner, E.A.; Pitzer, J.R. Developmental dynamics of student engagement, coping, and everyday resilience. In Handbook of Research on Student Engagement; Christenson, S.L., Reschly, A.L., Wylie, C., Eds.; Springer: Boston, MA, USA, $2012 ;$ pp. 21-44.

26. Schaufeli, W.B. What is engagement? In Employee Engagement in Theory and Practice; Truss, C., Alfes, K., Delbridge, R., Shantz, A., Soane, E., Eds.; Routledge: London, UK, 2013; pp. 1-37.

27. Bakker, A.B. An evidence-based model of work engagement. Curr. Dir. Psychol. Sci. 2011, 20, 265-269. [CrossRef]

28. Bakker, A.B.; Schaufeli, W.B. Positive organizational behavior: Engaged employees in flourishing organizations. J. Organ. Behav. 2008, 29, 147-154. [CrossRef]

29. Lippmann, S. Facilitating class sessions for ego-piercing engagement. N. Dir. Teach. Learn. 2013, 135, 43-48. [CrossRef]

30. Davis, F.D. A Technology Acceptance Model for Empirically Testing New End User Information Systems: Theory And Result; Sloan School of Management, Massachusetts Institute of Technology: Cambridge, MA, USA, 1986.

31. Hong, J.C.; Chang, J.E. Constructing an educational policy acceptance model to explore the attitude toward policy implementation: A perspective of using industrial competency standards system in universities of science and technology. J. Res. Educ. Sci. 2018, 63, 251-284. (In Chinese)

32. Hong, J.C.; Ye, J.H.; Fan, J.Y. Policy acceptance of technical vocational education: A perspective from a new act on field study. J. Res. Educ. Sci. 2019, 64, 177-207. (In Chinese)

33. Bhatiasevi, V. Acceptance of e-learning for users in higher education: An extension of the technology acceptance model. Soc. Sci. 2011, 6, 513-520. 
34. Giovanis, A.N.; Binioris, S.; Polychronopoulos, G. An extension of TAM model with IDT and security/privacy risk in the adoption of internet banking services in Greece. EuroMed J. Bus. 2012, 7, 24-53. [CrossRef]

35. Dantas, C.; Jegundo, A.L.; Quintas, J.; Martins, A.I.; Queirós, A.; Rocha, N.P. European Portuguese validation of usefulness, satisfaction and ease of use questionnaire (USE). In Recent Advances in Information Systems and Technologies: Advances in Intelligent Systems and Computing; Rocha, Á., Correia, A., Adeli, H., Reis, L., Costanzo, S., Eds.; Springer: Cham, Switzerland, 2017; Volume 570, pp. 561-570.

36. Bhattacherjee, A. An empirical analysis of the antecedents of electronic commerce service continuance. Decis. Support. Syst. 2001, 32, 201-214. [CrossRef]

37. Rakoczy, K.; Pinger, P.; Hochweber, J.; Klieme, E.; Schütze, B.; Besser, M. Formative assessment in mathematics: Mediated by feedback's perceived usefulness and students' self-efficacy. Learn. Instr. 2019, 60, 154-165. [CrossRef]

38. Crane, N.; Zusho, A.; Ding, Y.; Cancelli, A. Domain-specific metacognitive calibration in children with learning disabilities. Contemp. Educ. Psychol. 2017, 50, 72-79. [CrossRef]

39. Bandura, A. Social cognitive theory. In Handbook of Theories of Social Psychology; van Lange, P.M., Kruglanski, A.W., Higgins, E., Eds.; Sage: Thousand Oaks, CA, USA, 2012; Volume 1, pp. 349-373.

40. Cattelino, E.; Morelli, M.; Baiocco, R.; Chiru, A. From external regulation to school achievement: The mediation of self-efficacy at school. J. Appl. Dev. Psychol. 2019, 60, 127-133. [CrossRef]

41. Loscalzo, Y.; Giannini, M. Study engagement in Italian University students: A confirmatory factor analysis of the Utrecht work engagement scale: Student Version. Soc. Indic. Res. 2019, 142, 845-854. [CrossRef]

42. Demerouti, E.; Cropanzano, R. From Thought to Action: Employee Work Engagement and Job Performance; Psychology Press: New York, NY, USA, 2010.

43. Power, J. An examination of the influence of task difficulty on engagement, performance and self-efficacy formation within a computerised maze navigation task. Psychol. Rev. 2017, 84, 191-215.

44. Ariani, D.W. Relationship model of personality, communication, student engagement, and learning satisfaction. Bus. Manag. Educ. 2015, 13, 175-202. [CrossRef]

45. Richman, A. Everyone wants an engaged workforce how can you create it. Workspan 2006, 49, 36-39.

46. Schaufeli, W.B.; Martínez, I.M.; Marqués-Pinto, A.M.; Salanova, M.; Bakker, A.B. Burnout and engagement in university students: A cross-national study. J. Cross-Cult. Psychol. 2002, 33, 464-481. [CrossRef]

47. Sung, E.; Mayer, R.E. Affective impact of navigational and signaling aids to e-learning. Comput. Hum. Behav. 2012, 28, 473-483. [CrossRef]

48. Van Ryzin, M.J. Protective factors at school: Reciprocal effects among adolescents' perceptions of the school environment, engagement in learning, and hope. J. Youth Adolesc. 2011, 40, 1568-1580. [CrossRef]

49. Falloon, G. Young students using iPads: App design and content influences on their learning pathways. Comput. Educ. 2013, 68, 505-521. [CrossRef]

50. Dhevabanchachai, N.T.; Wattanacharoensil, W. Students' expectations, experiences, and career direction after in-house internship: The pedagogical role of the hotel training center in Thailand. J. Teach. Travel Tour. 2017, 17, 118-134.

51. Lee, C.S.; Chao, C.W. Intention to "leave" or "stay"-The role of internship organization in the improvement of hospitality students' industry employment intentions. Asia Pac. J. Tour. Res. 2013, 18, 749-765. [CrossRef]

52. Bandura, A. Guide for constructing self-efficacy scales. In Self-Efficacy Beliefs of Adolescents; Pajares, F., Urdan, T., Eds.; Age Information: Greenwich, UK, 2006; Volume 5, pp. 307-337.

53. Fredricks, J.A.; Blumenfeld, P.C.; Paris, A.H. School engagement: Potential of the concept, state of the evidence. Rev. Educ. Res. 2004, 74, 59-109. [CrossRef]

54. Alkhajah, T.A.; Reeves, M.M.; Eakin, E.G.; Winkler, E.A.H.; Owen, N.; Healy, G.N. Sit-stand workstations: A pilot intervention to reduce office sitting time. Am. J. Prev. Med. 2012, 3, 298-303. [CrossRef] [PubMed]

55. Vekiri, I. Information science instruction and changes in girls' and boy's expectancy and value beliefs: In search of gender-equitable pedagogical practices. Comput. Educ. 2013, 64, 104-115. [CrossRef]

56. Chiu, C.M.; Chiu, C.S.; Chang, H.C. Examining the integrated influence of fairness and quality on learners' satisfaction and web-based learning continuance intention. Inf. Syst. J. 2007, 17, 271-283. [CrossRef]

57. Hair, J.F.; Black, W.C.; Babin, B.J.; Anderson, R.E. Multivariate Data Analysis, 7th ed.; Pearson Prentice Hall: Upper Saddle River, NJ, USA, 2010.

58. Kenny, D.A.; Kaniskan, B.; McCoach, D.B. The performance of RMSEA in models with small degrees of freedom. Sociol. Methods Res. 2015, 44, 486-507. [CrossRef]

59. Cor, M.K. Trust me, it is valid: Research validity in pharmacy education research. Curr. Pharm. Teach. Learn. 2016, 8, 391-400. [CrossRef]

60. Green, S.B.; Salkind, N. Using SPSS for Windows and Macintosh: Analyzing and Understanding Data, 4th ed.; Prentice-Hall: Englewood Cliffs, NJ, USA, 2004.

61. Hancock, G.R.; Mueller, R.O. Structural Equation Modeling: A Second Course, 2nd ed.; Information Age: Charlotte, NC, USA, 2013.

62. Fornell, C.; Larcker, D.F. Evaluating structural equation models with unobservable variables and measurement error. J. Mark. Res. 1981, 18, 39-50. [CrossRef]

63. Byrne, B.M. Structural Equation Modeling with AMOS: Basic Concepts, Applications, and Programming; Routledge: London, UK, 2016. 
64. Villotti, P.; Balducci, C.; Zaniboni, S.; Corbière, M.; Fraccaroli, F. An analysis of work engagement among workers with mental disorders recently integrated to work. J. Career Assess. 2014, 22, 18-27. [CrossRef]

65. Macey, W.; Schinder, B. The meaning of employee engagement. Ind. Organ. Psychol. 2008, 1, 3-30. [CrossRef]

66. Guarnaccia, C.; Scrima, F.; Civilleri, A.; Salerno, L. The role of occupational self-efficacy in mediating the effect of job insecurity on work engagement, satisfaction and general health. Curr. Psychol. 2018, 37, 488-497. [CrossRef]

67. Bakker, A.B.; Vergel, A.I.S.; Kuntze, J. Student engagement and performance: A weekly diary study on the role of openness. Motiv. Emot. 2015, 39, 49-62. [CrossRef]

68. Huang, J.; Wang, Y.; You, X. The job demands-resources model and job burnout: The mediating role of personal resources. Curr. Psychol. 2015, 35, 562-569. [CrossRef]

69. Rose, P.S.; Teo, S.T.T.; Connell, J. Converting interns into regular employees: The role of intern-supervisor exchange. J. Vocat. Behav. 2014, 84, 153-163. [CrossRef]

70. Nooromid, M.J.; Mansukhani, N.A.; Deschner, B.W.; Moradian, S.; Issa, N.; Ho, K.J.; Stulberg, J.J. Surgical interns: Preparedness for opioid prescribing before and after a training intervention. Am. J. Surg. 2018, 215, 238-242. [CrossRef] [PubMed]

71. Chou, S.W.; Min, H.T.; Chang, Y.C.; Lin, C.T. Understanding continuance intention of knowledge creation using extended expectation-confirmation theory: An empirical study of Taiwan and China online communities. Behav. Inf. Technol. 2010, 29, 557-570. [CrossRef]

72. Bouw, E.; Zitter, I.; de Bruijna, E. Characteristics of learning environments at the boundary between school and work: A literature review. Educ. Res. Rev. 2019, 26, 1-15. [CrossRef]

73. Cinamon, R.G. Navigating work and study: Antecedents and outcomes of conflict and facilitation aspects of the work-school interface. J. Vocat. Behav. 2018, 104, 31-43. [CrossRef]

74. Deci, E.L.; Ryan, R.M. The "what" and "why" of goal pursuits: Human needs and the self-determination of behavior. Psychol. Inq. 2000, 11, 227-268. [CrossRef] 